\title{
OCEANOGRAPHIC PARAMETER ANALYSIS USING GIS AND GAM FOR POTENTIAL FISHING ZONE MAPPING OF BIGEYE TUNA (Thunnus obesus)
}

\author{
Bambang Semedi $^{\mathrm{a}, *}$, Hardoko ${ }^{\mathrm{a}}$, Abu Bakar Sambah ${ }^{\mathrm{a}}$ and Laily Septiani Agatha ${ }^{\mathrm{a}}$ \\ ${ }^{a}$ Faculty of Fisheries and Marine Science, Universitas Brawijaya \\ Jalan Veteran Malang, Jawa Timur 65145, Indonesia \\ *Corresponding Author: bambangsemedi@ub.ac.id
}

\begin{abstract}
This paper concerns investigations of the oceanographic parameters, such as sea surface temperature, chlorophyll-a, and depth, to describe the distribution of potential fishing zones of Bigeye Tuna (Thunnus obesus) in the waters south of Java, especially of the FMA (Fisheries Management Areas) 573. Bigeye Tuna commodity is one of the important economic fishes. We used two years (2018 and 2019) catch data including number of catch and fishing trip, provided by Cilacap fishing port. Sea surface temperature and chlorophyll-a data were obtained from satellite images Aqua MODIS, and the depth data were gained from satellite image ETOPO-1. Seven combined models of oceanographic parameters were analyzed using GAM (Generalized Additive Model) statistical analysis to show the lowest AIC (Akaike Information Criterion) values and the largest CDE (Cumulative Deviance Explained) values. The results showed that the combination of sea surface temperature, chlorophyll - a, and depth significantly describe the potential zone for the fishing of Bigeye Tuna (Thunnus obesus) in Southern Java waters. Statistic values of AIC and CDE were 28840.02 and $11.1 \%$ respectively. Bigeye Tuna widely distributed in the Southern Java waters spread from $7.3^{\circ} \mathrm{S}$ to $14.83^{\circ} \mathrm{S}$ and $102^{\circ} \mathrm{E}$ to $115.25^{\circ} \mathrm{E}$, with sea surface temperature range between $25^{\circ} \mathrm{C}$ to $30^{\circ} \mathrm{C}$, Chlorophyll - a ranged from 0.08 to $0.30 \mathrm{mg} / \mathrm{m}^{3}$, and at an average depth of 350 meters. The depth did not show a real effect on the catch. It was because of the fishermen settled the fishing locations close to the rumpon (Fish Aggregating Devices) areas.
\end{abstract}

Keywords: GAM, Bigeye Tuna, Southern Java, FMA 573, Satellite images,

\section{INTRODUCTION}

Indian Ocean has four dominant tuna species including Albacore Tuna, Skipjack Tuna, Yellowfin Tuna and Bigeye Tuna [1]. The Bigeye Tuna has a high economic value. The Bigeye Tuna migrate from one place to another which has oceanographic condition based on their habitat [2].

Oceanographic parameter that commonly use to study of fish habitat are sea surface temperature, chlorophyll$a$, and ocean current. The change of these oceanographic could affect to the change of fish behavior. Each parameter has different optimal range values of oceanic parameters [3]. One of the obstacles faced by fishermen in Indian
Ocean, especially around Southern Java waters is due to their limitation in determining potential fishing ground. Satellite remote sensing approaches is one of the methods that can help in providing data analysis to produce the information related to the potential of fishing ground. Remote sensing system is knowledge and art to get overall waters information [4].

The purpose of this study was to study the variability of oceanographic parameters to analyze the potential fishing ground of Bigeye Tuna (Thunnus obesus) in Southern Java waters using GAM. 


\section{METHODS}

\section{Study Area and Data Source}

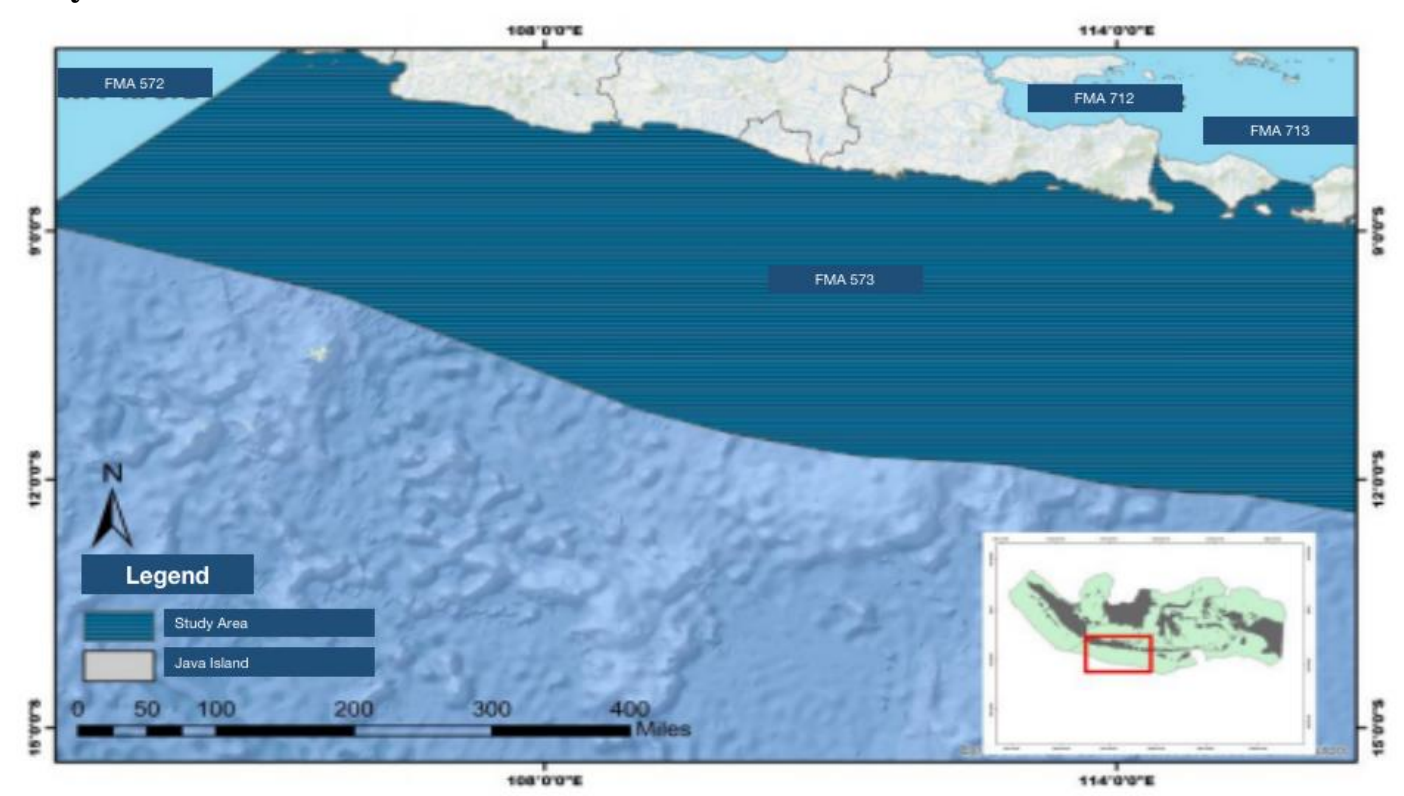

Figure 1. Study Area

This research based on GIS (Geographic Information System) conducted in the area of Eastern Indian Ocean Waters or Southern Java waters, especially of FMA 573 which is distributed form $8^{\circ} \mathrm{S}$ to $16^{\circ} \mathrm{S}$ and $105^{\circ} \mathrm{E}$ to $115^{\circ}$ E. Data used in this study were satellite images Aqua MODIS level 3 for oceanography parameter sea surface temperature and chlorophyll-a https://oceancolor.gsfc.nasa.gov/13/), and satellite images ETOPO-1 data for depth oceanographic parameter (https://ngcd.noaa.gov/mgg/global/), and fisheries data 2018 and 2019, provided by Cilacap Fishing Port .

Software used in this research as follows:

1. SeaDAS 7.2 Application

This application was used to This application was used to cut the research coverage area and save the GeoTIFF format, before processing it in the Er Mapper application.

2. ArcGIS 10.3

This application was used to extract multiple value to point for all oceanographic parameters, kriging for interpolation of FAD depth data, overlay data from GAM statistical analysis, and layout of the entire map.

3. Rstudio 3.5.1

This application was used for statistical analysis using the mgcv package with the GAM model.

\section{Analysis of GAM}

GAM was employed to estimate tuna fishing grounds that had been carried out in several Indonesian marine areas with a better level of accuracy [5], [6]. The preparation of the GAM model used mgcv packages in $\mathrm{R}$ software, the variables used were based on the smallest Akaike's Information Criteria (AIC) and the highest Cumulative Deviance Explained (CDE) values and the largest significant level of each formed GAM model [7].

The response variable $\mu \mathrm{i}$ (the number of catches of Bigeye Tuna in $\mathrm{kg}$ ) and predictor variables (SST, chlorophyll - a and depth) which can be found out the formula is as follows. 
$\mathrm{g}(\mu \mathrm{i})={ }^{\mathrm{o}}+\mathrm{s}_{1}(\mathrm{SST})+\mathrm{s}_{2}($ chlorophyl $)+\mathrm{s}_{3}$ (depth)

Based on the GAM package in the mgcv package, it is known that $\mathrm{g}$ is the spline smooth function, $\mu \mathrm{i}$ is the response variable and $\left(^{\circ}\right)$ is the constant coefficient.

\section{RESULT}

\section{Sea Surface Temperature (SST)}

The research of Bigeye Tuna (Thunnus obesus) in Southern Java Island at optimum temperature was 25$30^{\circ} \mathrm{C}$. Tuna could tolerate cold sea surface temperatures of $20^{\circ} \mathrm{C}$ and hot temperatures of $31^{\circ} \mathrm{C}$, however, most tuna fish were found in the temperature range of $25^{\circ} \mathrm{C}$ up to $29^{\circ} \mathrm{C}$. There were differences in the number of fishing coordinate points for each project area and month, where the number of catching coordinate points had spatial and temporal variability [8].

\section{Chlorophyll-a}

Chlorophyll-a is the food sources for fish species in the sea, the abundance of Chlorophyll - a in a water can be used as an indicator of the fertility of a water. The concentration of Chlorophyll-a could guarantee the sustainability of the fisheries sector both commercially in a water [9]. According to [10], Chlorophyll-a concentrations below 0.2 $\mathrm{mg} / \mathrm{m}^{3}$ were included in the low category. Results of this study, the average Chlorophyll-a in the Southern of Java Island waters was classified as good (high) with an average of 0.10 $\mathrm{mg} / \mathrm{m}^{3}-0.30 \mathrm{mg} / \mathrm{m}^{3}$.

\section{Depth}

Bigeye Tuna was mostly caught at an average depth of 350meter depth. Most of the fishermen located their gear closed to the FADs. According to [11], Bigeye Tuna is a species that has the farthest swimming layer and is able to adapt to low temperatures. According to [12] the water depth factor does not show a real effect on the catch and partially has an insignificant effect on the catch, this is due to fishing in the southern region of Java Island which is carried out in the FAD area.

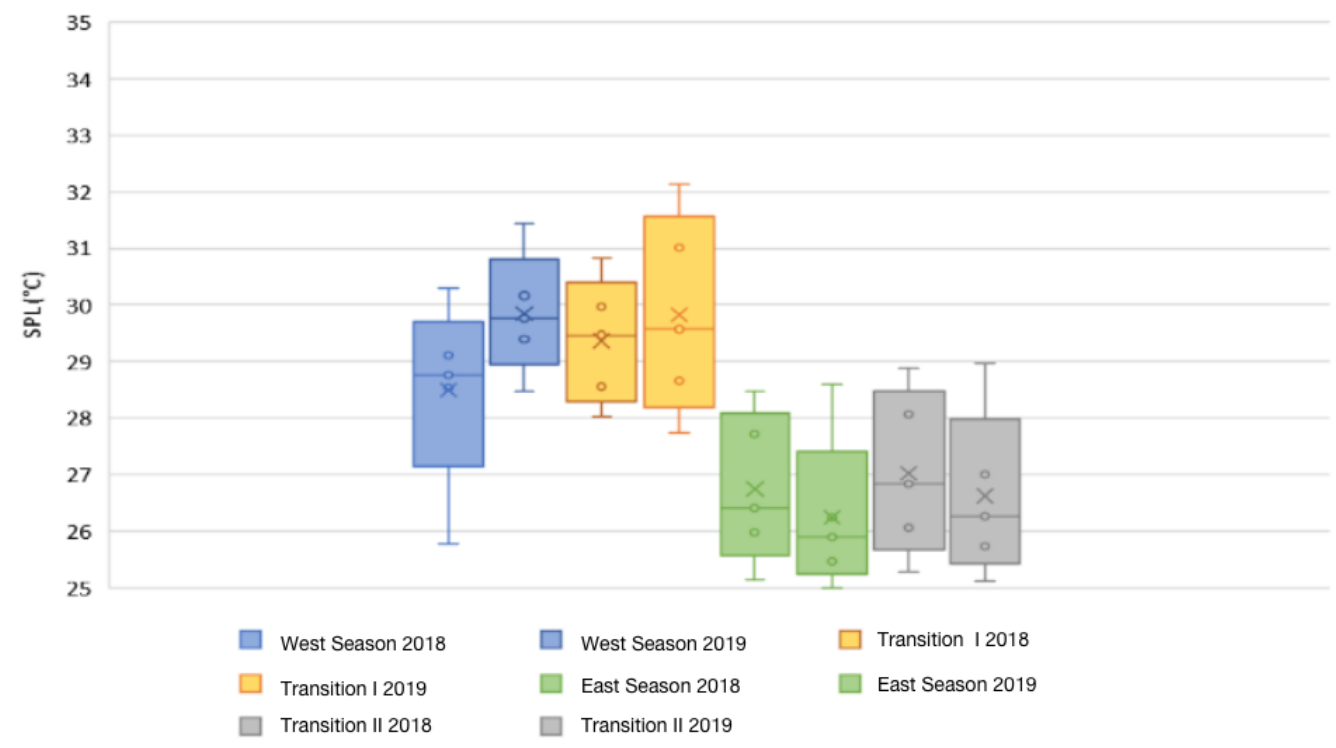

Figure 2. Sea surface temperature distribution 


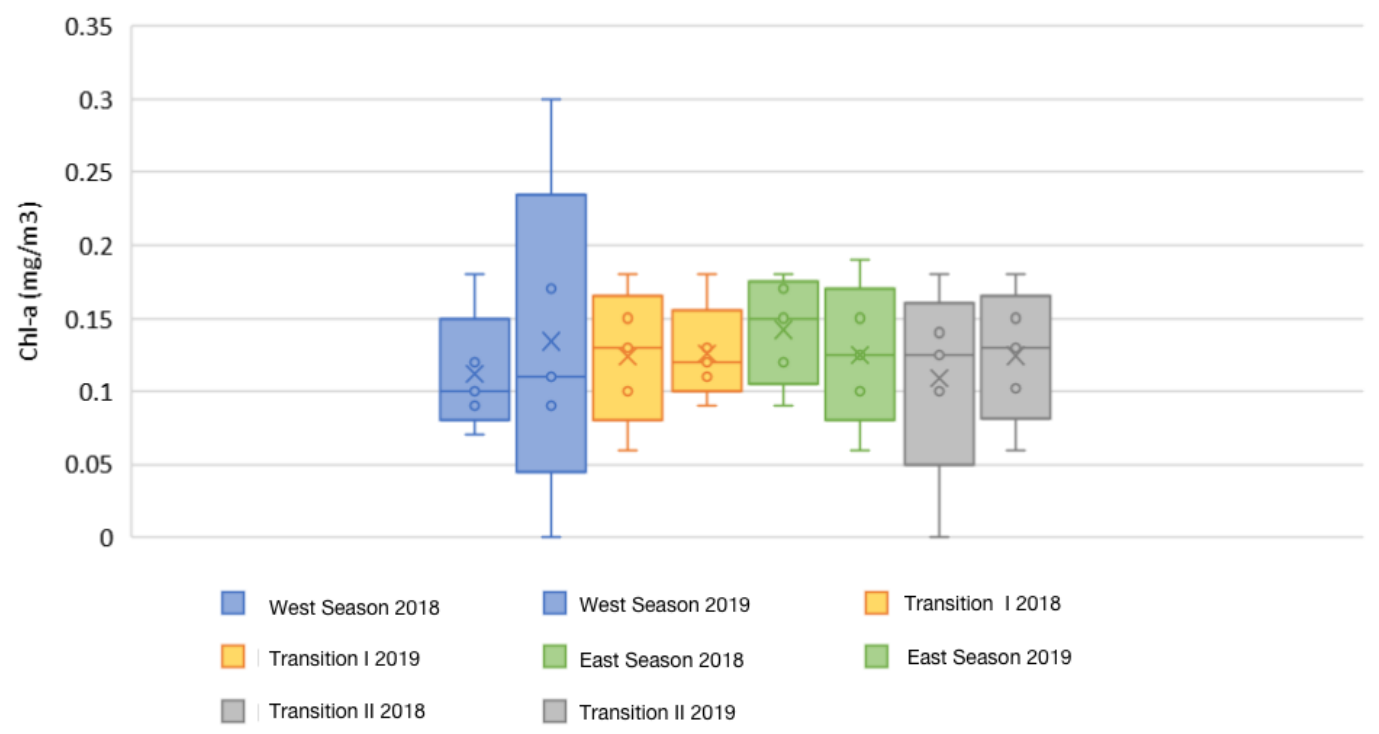

Figure 1. Chl-a distribution

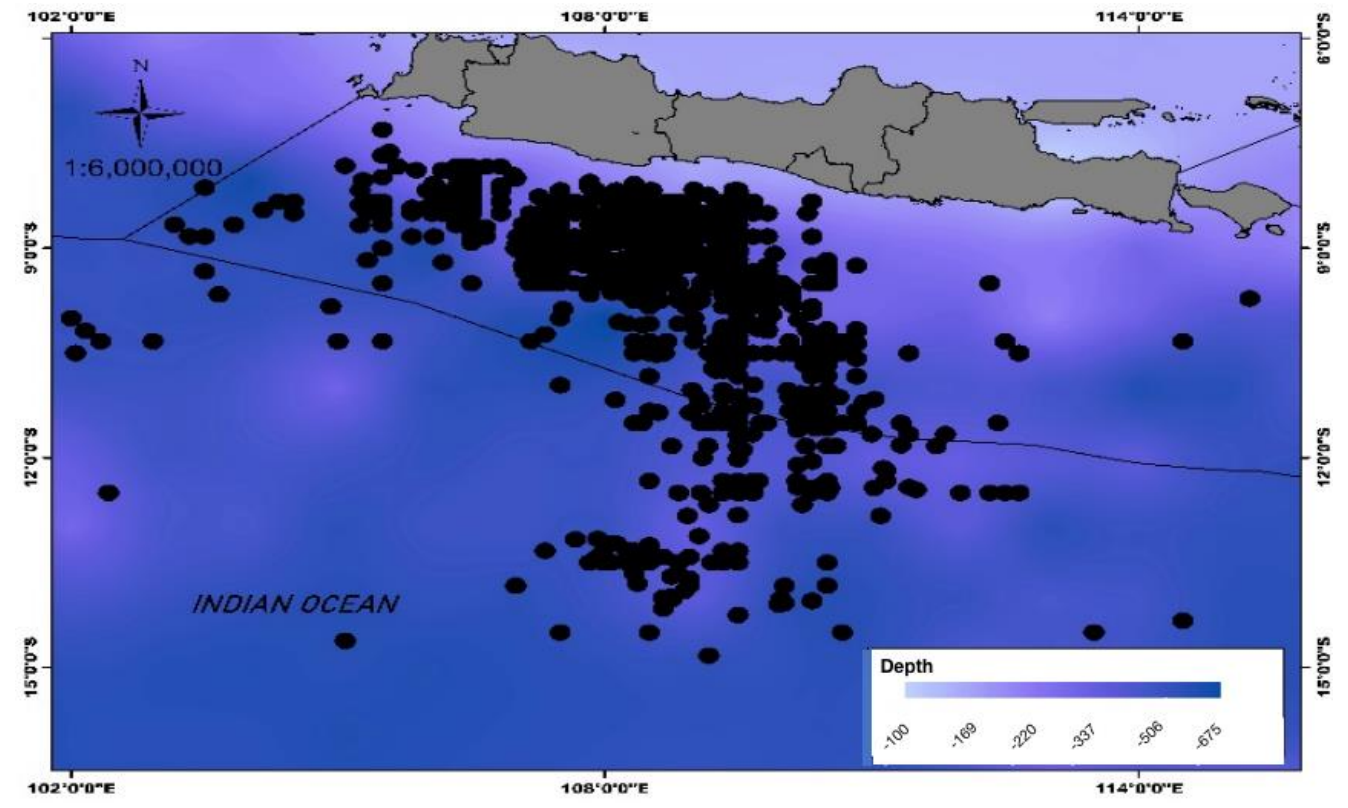

Figure 3. Fishing Ground Distribution Map Based on Depth

\section{CpUE}

The two-year data of CpUE could explain the coordinate point fishing locations, fishing trips, the number of catches in $\mathrm{kg} /$ trip, date, month, and year.

Based on the graph of Fig.5, it described that the highest fishing season index was in July 2019 with a value of $118.98 \%$, while the lowest was in January 2018 with a value of $17.27 \%$. The peak season for Bigeye Tuna at
FMA 573 occurs from May to July and the highest peak season was in June. The moderate number of catch season for Bigeye Tuna at FMA 573 occurs from March to April and August to November, while the low season of Bigeyes Tuna at FMA 573 was in December, which was at the beginning of the West Season. These fluctuations of the catch possibly correspond to upwelling and downwelling currents. 


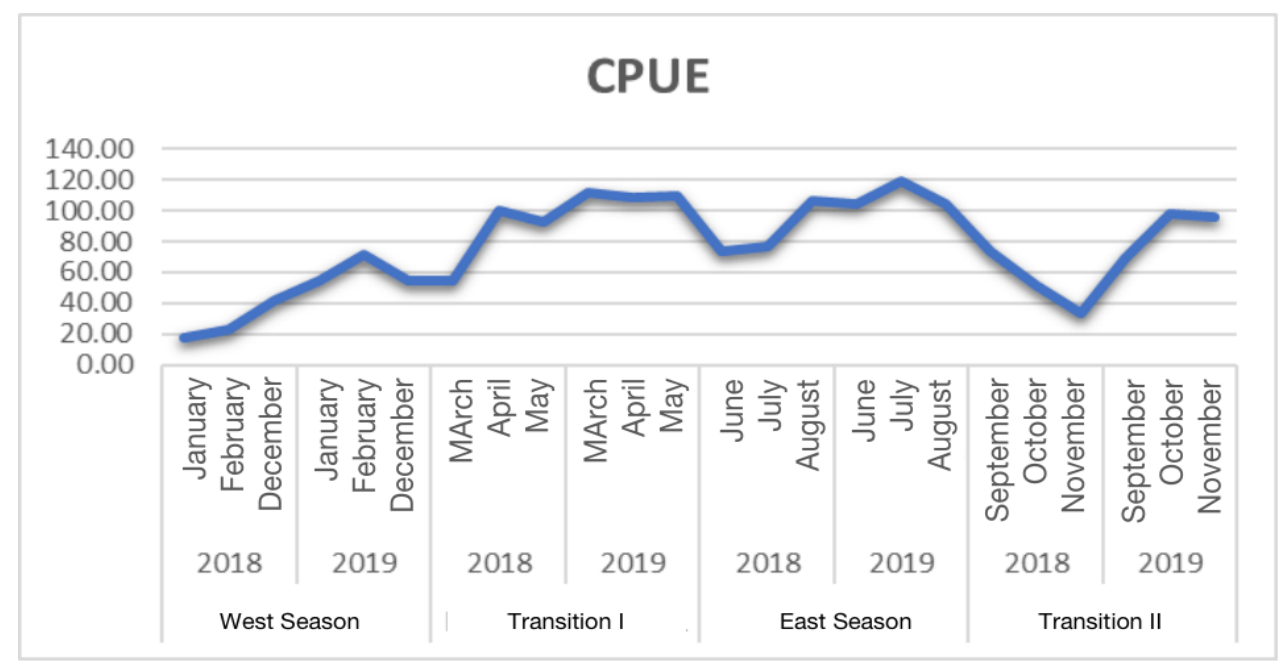

Figure 4. CpUE Based Season

\section{GAM Analysis}

This research used three oceanographic parameters such as SST, Chl-a and Depth. Based on the GAM, it is found that model 7 (Table 1), showed the best model in terms of the highest CDE value of all models and the lowest AIC value of all models. The AIC and
CDE values of model 7 was 28840.02 and the CDE values was $11.1 \%$. Based on graph analysis of GAM showed the value of each parameter that affected the Bigeye Tuna (Thunnus obesus). Sea surface temperatures ranged from $25^{\circ} \mathrm{C}$ to $32^{\circ} \mathrm{C}$, Chlorophyll - a ranged from 0.18 to $0.42 \mathrm{mg} / \mathrm{m}^{3}$, and for the depth was about $100-500 \mathrm{~m}$.

Table 1. GAM Model

\begin{tabular}{llllll}
\hline No & Model & Parameter & P-value & CDE & AIC \\
\hline 1 & Model 1 & SST & 0.569 & $0.18 \%$ & 290111.3 \\
2 & Model 2 & Chlorophyll - a & $5.28 \mathrm{e}-05 * * *$ & $1.73 \%$ & 28987.95 \\
3 & Model 3 & Depth & $<2 \mathrm{e}-16 * * *$ & $10.2 \%$ & 28846.42 \\
4 & Model 4 & SST & $0.00651 * *$ & $2.77 \%$ & 28978.73 \\
& & Chlorophyll - a & $1.35 \mathrm{e}-07 * * *$ & & \\
5 & Model 5 & SST & $0.02 *$ & $10.5 \%$ & 28843.25 \\
& & Depth & $<2 \mathrm{e}-16 * * *$ & & \\
6 & Model 6 & Chlorophyll - a & 0.0923 & $10.7 \%$ & 28842.85 \\
& & Depth & $<2 \mathrm{e}-16 * * *$ & & \\
7 & Model 7 & SST & 0.0769 & $11.1 \%$ & 28840.02 \\
& & Chlorophyll - a & 0.0904 & & \\
\hline
\end{tabular}



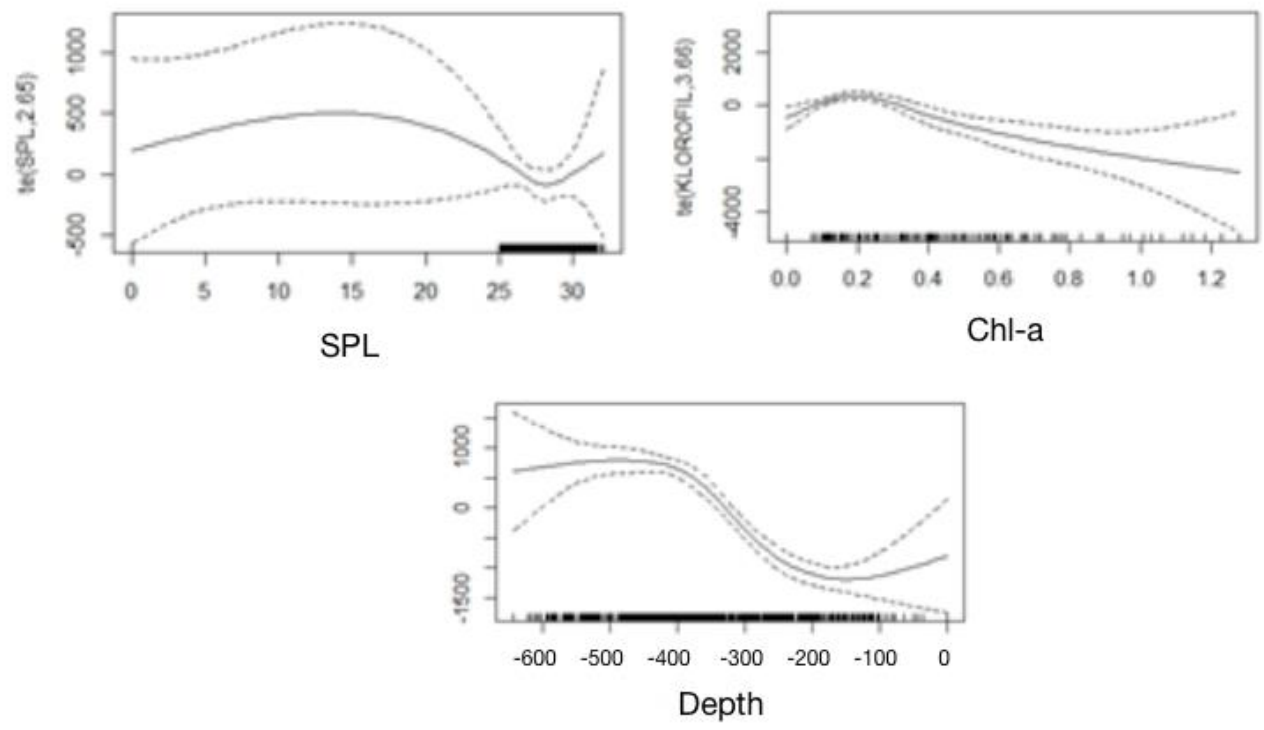

Figure 5. Smooth Curve Chart

\section{Mapping of Potential Fishing Ground for Bigeye Tuna}

Based on the GAM analysis Bigeye Tuna (Thunnus obesus) in the FMW 573 spatially distributed at Latitude of $-7.3^{\circ}$ $\mathrm{S}$ to $-14.83^{\circ} \mathrm{S}$ and Longitude of $102^{\circ} \mathrm{E}$ $115.25^{\circ} \mathrm{E}$.

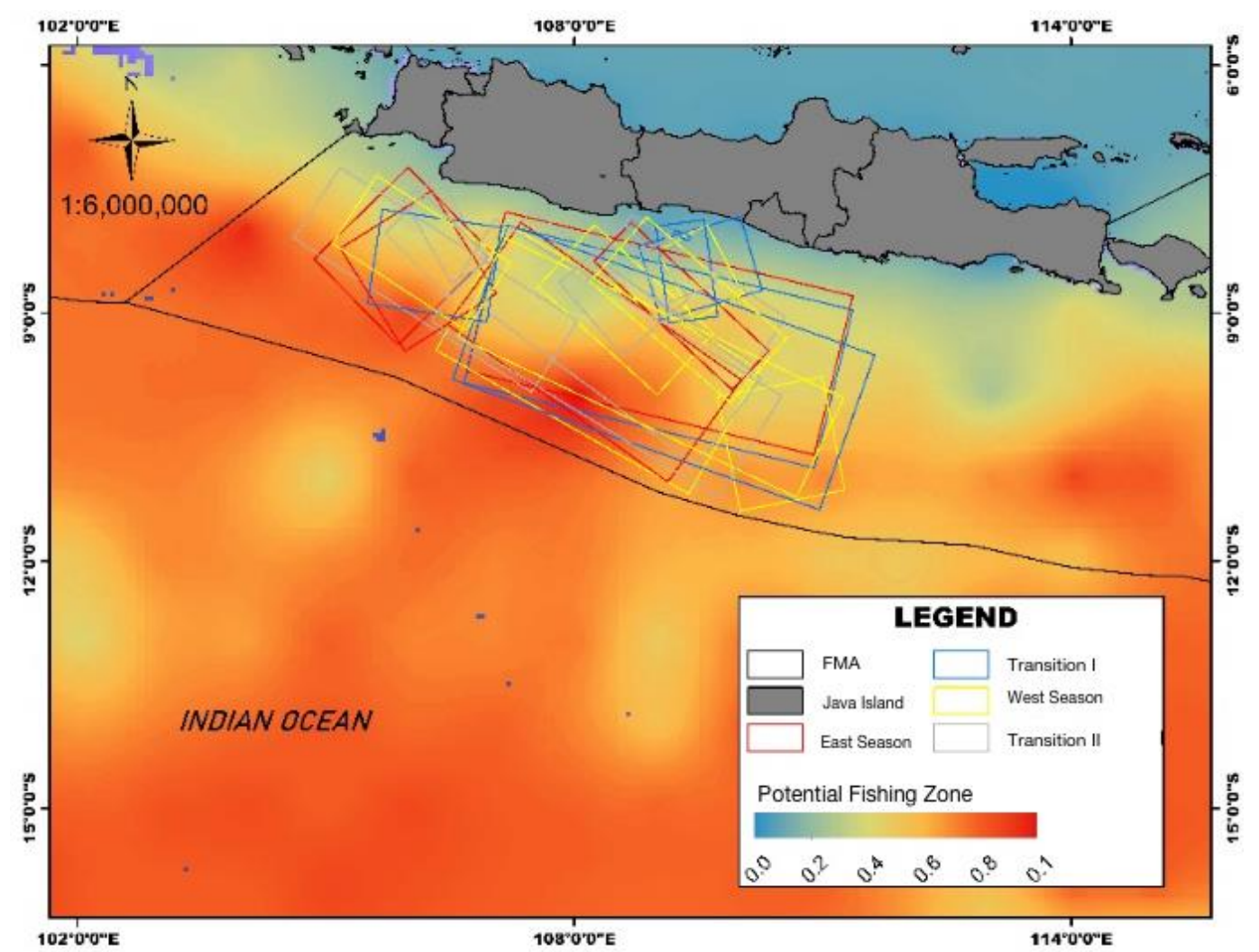

Figure 7. Potential Fishing Zone 


\section{CONCLUSION}

Combination of sea surface temperature, chlorophyll - a, and depth significantly describe the potential zone for the fishing of Bigeye Tuna (Thunnus obesus) in Southern Java waters. Statistic values of AIC and CDE were 28840.02 and $11.1 \%$ respectively. Bigeye Tuna widely distributed in the Southern Java waters spread from $7.3^{\circ} \mathrm{S}$ to $14.83^{\circ} \mathrm{S}$ and $102^{\circ} \mathrm{E}$ to $115.25^{\circ} \mathrm{E}$, with sea surface temperature range between $25^{\circ} \mathrm{C}$ to $30^{\circ} \mathrm{C}$, Chlorophyll-a ranged from 0.08 to $0.30 \mathrm{mg} / \mathrm{m}^{3}$, and at an average depth of 350 meters. The depth did not show a real effect on the catch. It was because of the fishermen settled the fishing locations close to the rumpon (Fish Aggregating Devices) areas.

\section{REFERENCES}

[1] Lee, P. F., Chen I.C., Tzeng W. N. 2005. Spatial and temporal distribution patterns of bigeye tuna (Thunnus obesus) in the Indian Ocean. Zoological Studies, 44 (2); 260-270.

[2] Sibagariang, O.P, Fauziyah., F Agustriani. 2011. Analisis Potensi Lestari Sumbe daya Perikanan Tuna Longline di Kabupaten Cilacap, Jawa Tengah. Maspari Journal, vol 03, hal 24-29.

[3] Tangke U., J.W.C Karuwal., A Mallawa, M. Zainuddin. 2016. Analisis Parameter Oseanografi Hubungan dengan Hasil Tangkapan Ikan Tuna Sirip Kuning di Perairan Maluku Utara. Jurnal Amansial. Ambon. Universitas Pattimura, Vol 5 (1) hal 1-9.

[4] Semedi, Handiyanto AL. 2013. Forecasting the fishing ground of small pelagic fishes in Makassar strait using moderate resolution image spectroradiometer satellite images. Journal of Applied Environmental and Biological Sciences, Vol 2, hal $29-34$.

[5] Wibawa, T. A. 2011. Pemanfaatan Data Satelit Oseanografi Untuk Prediksi Daerah Potensial Penangkapan Tuna Mata Besar (Thunnus obesus) di Samudra Hindia Selatan Jawa - Bali. Jurnal Segar. Vol 7 (2).

[6] Zainuddin M, Najamuddin A, Farhum A, Hajar I. 2013. Pemetaan Zona Potensial Penangkapan Ikan Cakalang Pada Musim Peralihan Berbasis Remote Sensing Dan Sistem Informasi Geografis di Teluk Bone - Laut Flores. Jurnal Seminar Nasional Universitas Gajahmada.

[7] Wood, Simon N. 2006. Generalized Additive Models: An Introduction with R. Journal of Statistical Software 16.

[8] Marpaung, Sartono., Rossi H., Teguh Prayogo., Ety Parwati., Syifa W,A., Muchlisin A. 2017. Analisis Informasi Zona Potensi Penangkapan Ikan (ZPPI) Harian di Perairan Laut Indonesia dan Sekitarnya. Seminar Nasional Penginderaan Jauh. PUSFATJALAPAN.

[9] Mursyidin, Khairul Munadi, dan Muchlisin Z. A. 2015. Prediksi Zona Tangkapan Ikan Menggunakan Citra Klorofil-a Dan Suhu Permukaan Laut Satelit Aqua MODIS Di Perairan Pulo Aceh. Journal Rekayasa Elektrika. Vol 11 (5).

[10] Kurniawati F., Sanjoto T. B., Juhadi. 2015. Pendugaan Zona Potensi Penangkapan Ikan Pelagis Kecil di Perairan Laut Jawa Pada Musim Barat dan Musim Timur Dengan Menggunakan Citra Aqua 
Modis. Jurnal Geo Image. Vol 4 (2).

[11] Soepriyono, Y. 2009. Teknik dan Manajemen Penangkapan Tuna Melalui Metode Longline.

Penerbit Bilas Utama. Denpasar.

[12] Sarifuddin. 2000. Studi Tentang Pengaruh Faktor Oseanografi Terhadap Hasil Tangkapan. Tesis. Universitas Hasanudin. Makasar 